DE DE GRUYTER OPEN

Research Article

(C) 2017 Perdomo-Charry et.al. This is an open access article licensed under the Creative Commons Attribution-NonCommercial-NoDerivs License (http://creativecommons.org/licenses/by-nc-nd/3.0/).

\title{
The Effect of Exploitation Capacities on Organizational Performance: An Empirical Analysis

\author{
Geovanny Perdomo-Charry
} PhD in Administration. CEIPA Business School,
Medellin, Colombia

\section{Nelson Lozada Barahona}

Mag. in Administration. Department of Administrative Sciences, Universidad de Antioquia, Medellin, Colombia

Alexander Zuñiga-Collazos

PhD in Tourism Management, Faculty of Economics Sciences, University of San Buenaventura-Cali - Colombia

Doi: $10.1515 / \mathrm{mjss}-2017-0037$

\begin{abstract}
The effect of exploitation capacity (EC) vis-à-vis organizational performance (OP) has not been sufficiently studied and has low empirical evidence in developing countries such as Colombia. Absorption capacity based on exploitation capacity (EC) is considered to have been relevant for organizations in developing countries to significantly increase their performance via innovation. We examined the effect of exploitation capacity versus organizational performance using a sample of 227 companies located in Medellin, Colombia. The main findings indicate that companies can generate exploitation capacities in order to increase organizational performance, essentially seeking to combine information from different sources for their benefit, thereby directly contributing to the growth of benefits in the companies under study.
\end{abstract}

Keywords: Exploitation capacity, organizational performance, SEM

\section{Introduction}

Corporate studies already recognize and value absorption capacity as an important notion. Its relevance is based on the possibility of creating and capturing new knowledge for the development and growth of the company from a real and potential approach, as research on this capacity's construct is multidimensional (Zahra \& George, 2002; Nieto \& Quevedo, 2005; Lane et al., 2006; Arbussa \& Coenders, 2007; Grimpe \& Sofka, 2009; Malhotra et al., 2015).

Therefore, it can be noted that Absorption Capabilities (AC) have increased considerably in the literature over the last two decades, thereby expanding their conception, levels and research dimensions both in companies and the environment. Hence, AC has acquired a second-order construct denomination, composed of four-first order variables: 1) acquisition, 2) assimilation, 3) transformation and 4) operation (Camisón \& Forés, 2010, Kostopulos et al., 2011, Flatten et al., Engelen et al., 2014, Enkel \& Heil, 2014).

Thus, the challenge of current research is to bridge the knowledge gap by studying the 
relationship between first-order constructs of $A C$, such as $E C$, with other constructs or variables such as OP in developing countries. This statement is interesting, given the scarcity of empirical studies in the literature regarding the effect that EC has on OP. This paper undertook to analyze the effect of exploitation capacities on organizational performance, in a representative sample of organizations located in the city of Medellin, Colombia.

\section{Exploitation Capabilities}

According to Zahra and George (2002), ACs are conceived as the ability of an organization to generate processes, routines and business dynamics that facilitate generation of value based on knowledge acquired in the external environment of the company. This is done through acquisition, assimilation, transformation and exploitation. These are multidimensional variables which facilitate an approach to the four dimensions from different viewpoints (Table 1).

Table 1. Dimensions of Absorption Capacity (AC)

\begin{tabular}{|l|l|}
\hline Dimension & Definition \\
\hline $\begin{array}{l}\text { Acquisition } \\
\text { capacity }\end{array}$ & It refers to the possibility of obtaining knowledge from sources external to the company. \\
\hline $\begin{array}{l}\text { Assimilation } \\
\text { capacity }\end{array}$ & $\begin{array}{l}\text { It is associated with the possibility that the new external knowledge is understood and } \\
\text { learned by the members of the company. }\end{array}$ \\
\hline $\begin{array}{l}\text { Transformation } \\
\text { capacity }\end{array}$ & $\begin{array}{l}\text { It is given by combining the two previous capabilities to create new knowledge that is } \\
\text { useful for generating value in the company. }\end{array}$ \\
\hline $\begin{array}{l}\text { Exploitation } \\
\text { capacity }\end{array}$ & $\begin{array}{l}\text { Development of routines that allow the generation of new processes, products and } \\
\text { systems that strengthen current capabilities, or which allow for the development of new } \\
\text { capabilities in the company. }\end{array}$ \\
\hline
\end{tabular}

Source: Authors' own work, based on Zahra \& George (2002), Jansen (2005) and Volberda et al. (2010).

According to the table above - and in light of the purpose of this paper - the dimensions to be analyzed are Exploitation Capacities (EC), whose fundamental objective is to study the effect that EC produces on organizational performance. Therefore, EC is regarded in this paper as the capacity that develops routines to apply and use knowledge, thereby enabling the creation of new goods, systems and processes that improve current competencies and create new entrepreneurial competencies (Cohen \& Levinthal, 1990) all the while increasing OP.

\section{Organizational Performance}

Increasing OP has been one of the core issues of management (Neely, 1999). In practice, entrepreneurs, leaders and scholars are concerned with understanding and analyzing this subject, as evidenced by the extraordinary number of articles on the subject (Choong, 2014). In regards to this understanding, Neely (2002) points out that OP can be understood as the level of achievement attained by an organization, through information processing and analysis with the aim of supporting decision making.

In this vein, Forza and Salvador (2000) argue that OP is management based on (i) providing communication and (ii) collecting, processing and delivering information on performance and activities of people which are not developed by individuals. Conversely, Julnes (2007) states that $\mathrm{OP}$ is understood as any services, products and programs generated by the company which produce information about the organization's performance.

It is worth noting that it is only as late as the late sixties that organizational measurement systems (OMS) are introduced, based on different metrics, measurement forms, and indicators (Johnson, Johnson, Kaplan \& Norton 1992; Kaplan \& Norton 1996; White, 2008). However, Choong (2014) deems it necessary to more appropriately define conceptual frameworks that combine specific research interests, for the proper development of the OMS. 
Therefore, measurement researchers have argued in favor of and against a particular performance measurement system called OMS (Choong, 2014), as research on this topic is conducted in a prescriptive or historical way, thus leaving aside scientific, mathematical or logical analyses (Neely 2005, Gunasekaran \& Kobu 2007, Petersen et al, 2009, Sole \& Schiuma 2010; \& Choong 2014), related to innovation - amongst other variables.

In fact, some research highlights the importance of the level of business innovation as a vital aspect for organizational performance analysis (Danneels \& Kleinschmidt, 2001). One of the studies indicates that organizational innovation has a direct impact on performance, understood in terms of sales growth, market share and profitability (Akgün et al., 2007). Another paper states that OP linked to innovation can be studied from the perspective of return on investment for shareholders. In turn, this would allow for comparisons to similar organizations both in terms of potential investors and shareholders, so as to establish the investment level for a company (Ellinger et al., 2002).

\section{Exploitation and Performance Capabilities}

The literature shows that the relationship between companies' absorption capacities and organizational performance is positive (Chen et al., 2009; Jiménez-Jiménez y Sanz-Valle, 2011; Leal-Rodriguez et al., 2014; Tsai, 2001). Likewise, Ali et al. (2016) argue that absorption capacities are one of the most important determinants of a company's ability to acquire, assimilate, transform and effectively operate new knowledge, aiming to increase innovation while directly impacting OP. As a result, organizations are making efforts to increase $A C$, in order to exploit new knowledge both internally and externally. Consequently, this contributes to high performance (Ali et al. 2016). Companies that have knowledge-building capabilities will eventually have a better understanding of new technologies, which will result in the generation of new ideas and the development of new innovative products, services, processes or businesses (Tsai, 2001) thereby impacting OP. Therefore, we propose the following hypothesis.

Hypothesis: Exploitation capacities have a positive effect on organizational performance.

\section{Methodology}

Data collection was conducted by way of the use of a questionnaire-type instrument. In order to verify validity of the instrument used, we utilized the construct validity (factor analysis) method. In terms of factor reliability, we measured the Cronbach's alpha coefficient. The latter was calculated in both cases as $>0.800$, which is satisfactory. A 5-point Likert scale was used; in the case of exploitation capacities, (1) means absolutely nothing, and (5) meant completely done. In the case of organizational performance, (1) meant not important at all, and 5 meant very important.

Confirmation of the measurement model was performed using confirmatory factor analysis (CFA), thus seeking to test the relationship between the latent variables and the respective items. The validation of the hypothesis relationship was performed under the model of structural equations, where data were analyzed using EQS 6.3.

The questionnaire administered with the companies enquired respondents as to the development and evolution of the EC and the OP, alluding to what happened in the last 3 years of operation, as suggested by the literature (Flatten et al., 2011a; 2011b , Akling et al., 2007, Ellinger et al., 2002). In order to clarify the relationship analyzed, the questionnaire clarified that growth - in terms of volume and number of sales - is growth achieved thanks to current and new customers. Conversely, in the case of market share growth, it is the comparison with their competitors in the same period of time. The conceptual model and its relationships can be seen in Figure 1. 


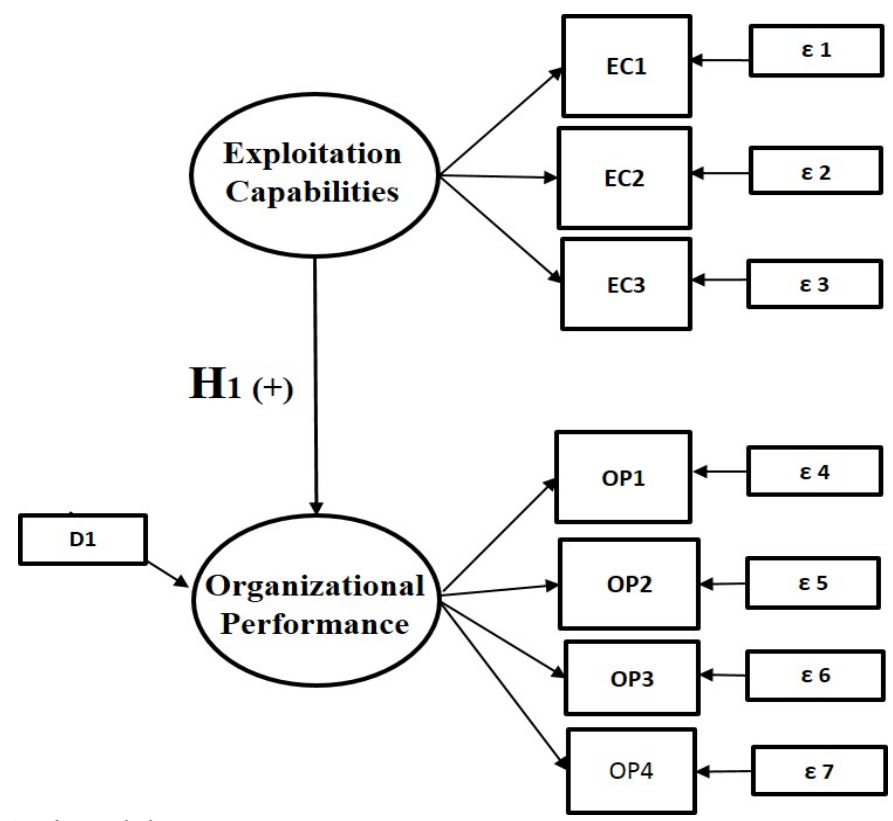

Figure 1. Conceptual model

\section{Sample}

The structural equations model (SEM) was examined using a sample of 227 valid responses. It also shows the relevance of obtaining an adequate sample in this type of analysis. In addition, some scientists recommend that an appropriate sample should have at least 200 informants (Garver \& Mentzer 1999; Sivo et al., 2006; Hoe, 2008), although there is no consensus in empirical studies as to the optimal level of its sample size (Schreiber et al., 2006, Kline, 2010, McQuitty, 2004).

The sample is composed of organizations located in Medellin, Colombia, which belong to the industrial and service sectors. 227 managers or leaders of the innovation area answered the questionnaire. As for company size, the Ministry of Commerce, Industry and Tourism in Colombia believes that organizations with up to 200 employees qualify as being small and medium enterprises, which in the case of this study make up $88.5 \%$ of the sample.

\section{Results}

The research comprises two moments to be analyzed and to explain the findings under the SEM: (i) the evaluation's measurement model, and (ii) the structural model test. Table 2 shows that the means reached are considered relatively low for both variables, with results between 3.35-3.38, and similar standard deviation between 1.06-1.15. The correlation value for latent variables is above the appropriate level (0.386) with significance vis-à-vis $\rho<0.05$.

Table 2. Correlations, means, standard deviations, reliability.

\begin{tabular}{clcccc}
\hline Variables & $M$ & $S D$ & 1 & 2 \\
1. & Exploitation capacities & 3.38 & 1.15 & $(0.882)$ & \\
2. & Organizational performance & 3.35 & 1.06 & $0.386^{*}$ & $(0.926)$ \\
\hline
\end{tabular}

$\mathbf{N}=226$; Alfa reliability is show on the diagonal

$* \rho<0.05$

The measurement model's normal validity requirements are met in a satisfactory fashion (see 
Appendix A). The loads of all items are above 0.882 or 0.926 , with a significance vis-à-vis $\rho<0.05$. the latter indicates the convergent validity of each of the items. High reliability is suggested, since Cronbach alpha values are greater than 0.8 , as well as composite reliability above 0.9 . At the construct level, the EVA values are greater than 0.5 ; these results confirm the existence of discriminant validity.

The structural model was estimated with the aim of verifying potential colinearity. The results show minimum collinearity, along with VIF outflows below the threshold (5). Therefore, collinearity in the structural model predictor construct is not a problem. The R2 value is above the appropriate latent level (Falk \& Miller, 1992); the R2 value among the variables is 0.386 with significance of $\rho$ $<0.05$.

The measurement model achieved good values of these indices: BBNFI, BBNNFI, CFI, and IFI. Values above 0.90 in the BBNFI and BBNNFI indices allow us to observe an adequate goodness of fit of the model (Ullman, 2001). Indeed, the values of the current model comply with appropriate values. Similarly, values above 0.90 in the TPI index refer to acceptable quality of fit, and values above 0.95 mean a very good model. The results for this index under this study are 0.962 (Hu \& Bentler, 1999). The value obtained for RMSEA for the measurement model can be considered appropriate.

Values between 0.05 and 0.08 in RMSEA evidenced the presence of an acceptable model (Browne \& Cudeck, 1993); the current model shows a value of 0.108 . Another important aspect is the load factors of each of the items. As for $\mathrm{EC}$, this was the most important variable given its high load (0.907), on account of the fact that companies "are good at combining information from different sources for their benefit", followed by the following statement: "the company has the ability to work more effectively by adopting new technologies" (0.825), and "managers support the development of prototypes" (0.802).

In regards to OP, the most relevant variable was the growth of profits $(0.911)$, followed by the other three variables with slightly similar values, albeit they have a high load: return on investment (0.871), sales growth (0.853), and market share growth (0.811). These findings demonstrate the existence of a direct and positive relationship between CT and OP (Hair et al., 2013). Consequently, the hypothesis is corroborated. The results are shown in Figure 2.

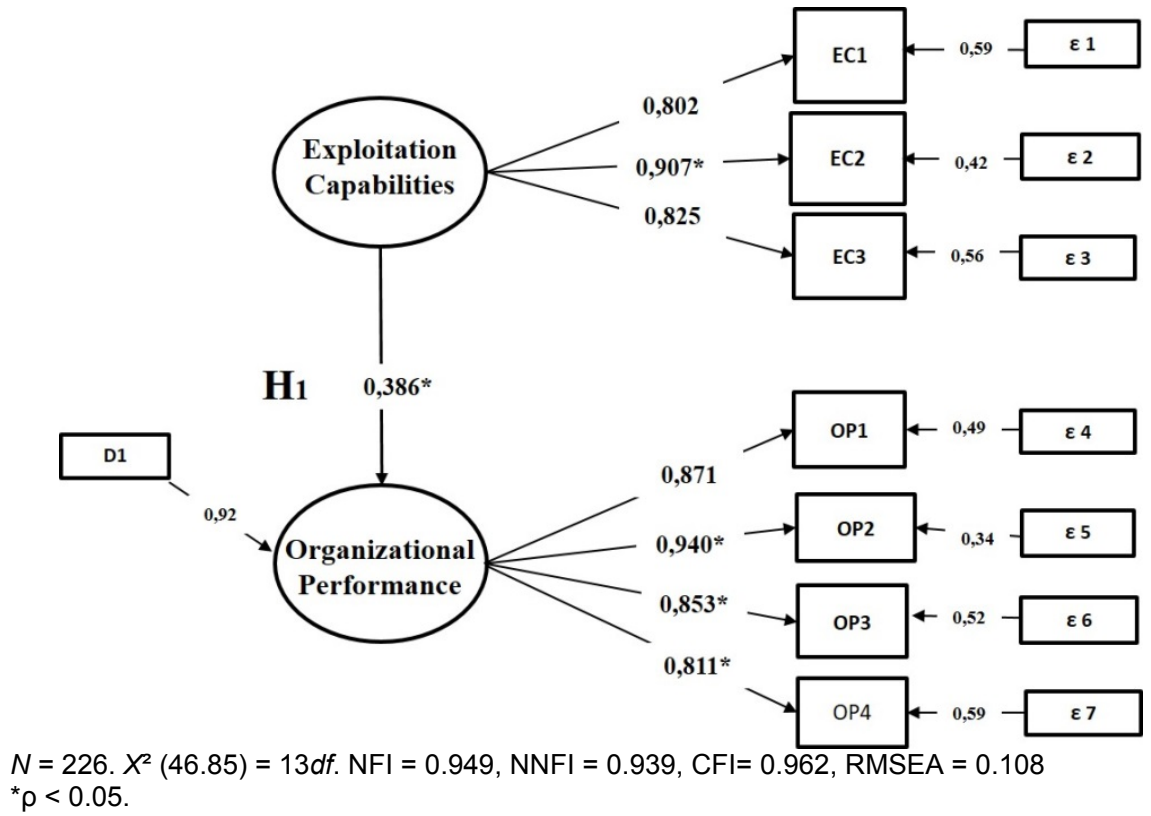

Figure 2. Results of the structural model 


\section{Conclusions and Discussion}

The findings obtained expand the relevant empirical evidence supporting the theoretical development. These results also further the empirical validation of the study, given the high level of compression of the EC - OP ratio in the real sector (Zahra \& George, 2002; Jansen, 2005; Volberda et al., 2010; Cohen \& Levinthal, 1990; Flatten et al., 2011a; 2011b).

The organizational dynamics wherein firms compete in developing countries are those found in developed countries; therefore, the empirical findings of the research make it possible to argue the difference in the weight of the factors analyzed. In the specific case of the sample of organizations studied, the weight obtained by the variable "they are good for combining information from different sources for their benefit", and in the case of the OP, the most important variable is "growth of benefits" of companies.

Because of their multidimensionality attributes, ECs warrant more detailed analysis in their relationship with the OP, where this research contributes in a concrete way, since it has allowed with empirical evidence to validate the relation - more precisely to recommend that the good combination of information from different sources for business benefit is a guarantee to drive the growth of benefits in companies. The findings show that there is a direct and positive relationship between EC and OP, which allows us to conclude that companies that develop CE increase their chances of improving their OP.

Future studies should delve in the relationship of EC with specific OP variables such as innovative, financial and non-financial performance, so as to facilitate a better understanding of this relationship due to the specificity of the level of analysis. In addition, the study can be extended to a significant group of organizations at the national level, which would in turn go to facilitate the collection of relevant information in different places of Colombia.

\section{References}

Akgün, A. E., Keskin, H., Byrne, J. C., \& Aren, S. (2007) 'Emotional and learning capability and their impact on product innovativeness and Organizational performance', Technovation, 27 (9), 501-513.

Arbussa, A., \& Coenders, G. (2007) 'Innovation activities, use of appropriation instruments and absorptive capacity: Evidence from Spanish Organizationals '. Research Policy, 36 (10), 1545-1558.

Brown, T. A. (2006). Confirmatory Factor Analysis for Applied Research. New York: Guilford Press. [Taylor \& Francis Online]

Browne, M. W. \& Cudeck, R. (1993) Alternative ways of assessing model fit. Sage Focus Editions, 154, 136136.

Camisón, C., \& Forés, B. (2010). 'Knowledge absorptive capacity: New insights for its Conceptualization and measurement '. Journal of Business Research, 63 (7), 707-715.

Choong, K. K. (2014). 'Has this large number of performance measurement publications contributed to its better understanding? A systematic review for research and applications ', International Journal of Production Research, 52 (14), 4174-4197.

Cohen, W.M., \& Levinthal, D.A., (1990). 'Absorptive capacity: a new perspective on learning and innovation'. Administrative Science Quarterly, 35, 128-152.

Danneels, E., \& Kleinschmidt, E.J., (2001). "Product innovativeness from the Organizational's perspective: its dimensions and their relation with project selection and performance". Journal of Product Innovation Management, 18, 357-373.

Ellinger, A.D., Ellinger, A.E., Yang, B., Howton, S.W. (2002). 'The relationship between the learning organization concept and Organizational's financial performance: an empirical assessment '. Human Resource Development Quarterly, 13 (1), 5-21.

Engelen, A., Kube, H., Schmidt, S., \& Flatten, T. C. (2014). Entrepreneurial orientation in turbulent environments: The moderating role of absorptive capacity', Research Policy, 43(8), 1353-1369.

Enkel, E., \& Heil, S. (2014). Technovation Preparing for distant collaboration: Antecedents to potential absorptive capacity in cross-industry innovation ', Technovation, 34 (4), 242-260.

Falk, R.F., \& Miller, N.B. (1992). A primer for soft modeling. Akron, OH: Univ. Akron Press.

Forza, C. \& Salvador. F. (2000). Assessing Some Distinctive Dimensions of Performance Feedback Information in High Performing Plants. International Journal of Operations \& Production Management, 20 (3), 359385.

Flatten, T. C., Engelen, A., Zahra, S. a., \& Brettel, M. (2011a). 'A measure of absorptive capacity: Scale 
development and validation ', European Management Journal, 29 (2), 98-116.

Flatten, T. C., Greve, G. I., \& Brettel, M. (2011b). 'Absorptive Capacity and Organizational Performance in SMEs: The Mediating Influence of Strategic Alliances ', European Management Review, 8 (3), 137-152.

Garver, M. S. \& J. T. Mentzer. (1999). Logistics Research Methods: Employing Structural Equation Modeling to Test for Construct Validity', Journal of Business Logistics, 20 (1), 33-57.

Grimpe, C. \& Sofka, W. (2009). 'Search patterns and absorptive capacity: Low- and high-technology sectors in European countries ', Research Policy, 38 (3), 495-506.

Hair, J.; Anderson, R.; Tatham, R. \& Black, W. (2005). Análisis Multivariante. 5ta. Edición, Prentice Hall, España.

Hoe, S. L. (2008). 'Issues and Procedures in Adopting Structural Equation Modeling Technique'. Journal of Applied Quantitative Methods, 3 (1), 76-83

Hu, L. \& Bentler, P. (1999). 'Cutoff criteria for fit indexes in covariance structure analysis: conventional criteria versus new alternatives", Structural Equation Modelling, 6, 1-55.

Jansen, J. J. P., Van Den Bosch, F. A. J., \& Volberda, H. W. (2005). 'Managing potential and realized absorptive capacity: How do organizational antecedents matter? ', Academy of Management Journal, 48, 999-1015.

Johnson, H. T. (1981). 'Towards an Understanding of Nineteenth Century Cost Accounting', The Accounting Review, 56 (3), 510-518.

Johnson, H. T., and Kaplan, R. S. (1987) 'Relevance Lost - The Rise and fall of Management Accounting. Boston, MA: Harvard Business School Press ', Journal of Business Research, 64 (4), 408-417.

Julnes, P. (2007). Performance Measurement. Encyclopedia of Public Administration and Public Policy. Broken Sound Parkway, NW: CRC Press

Kaplan, R. S. \& Norton P. N. (1992). "The Balanced Scorecard: Measures That Drive performance", Harvard Business Review, 70 (1), 71-79.

Kaplan, R. S., \& Norton P. N. (1996). 'Using the Balanced Scorecard as a Strategic Management System', Harvard Business Review, 74(1), 75-85.

Kline, P. 1994. An Easy Guide to Factor Analysis. New York, NY: Routledge.

Kline, R. B. 1998. Principles and Practice of Structural Equation Modeling. New York: Guilford Press.

Kline, Rex B. 2010. Principles and Practice of Structural Equation Modeling, Series Editor's Note by Todd D. Little. New York: The Guilford press.

Kostopoulos, K., Papalexandris, A., Papachroni, M., \& loannou, G. (2011). Absorptive capacity, innovation, and financial performance '. Journal of Business Research, 64(12), 1335-1343.

Lane, P. J. \& Lubatkin, M. (1998). Relative absorptive capacity and inter-organizational learning, 19 (November 1996), 461-477.

Lane, P. J., Koka, B. R., Pathak, S., Lane, P. I., \& Thak, S. P. (2006) 'The reification of absorptive capacity: a critical review and rejuvenation of the construct", 31 (4), 833-863.

Malhotra, A., Gosain, S., \& Sawy, O. A. El. (2015). 'Absorptive Capacity Configurations for Partner Gearing Supply Chains '. Enabled Market Knowledge, 29 (1), 145-187.

Maskell, B. H. (1991). Performance Measurement for World-Class Manufacturing. Cambridge, MA: Productivity Press.

McQuitty, S. (2004) 'Statistical Power and Structural Equation Models in Business Research ', Journal of Business Research, 57 (2), 175-183.

Neely, A. (1999). 'The performance measurement revolution: why now and what next?', International Journal of Operations \& Production Management, 9 (2), 205-228.

Neely, A. D. (2002). Business Performance Measurement. Cambridge: Cambridge University Press

Nieto, M., \& Quevedo, P. (2005). 'Absorptive capacity, technological opportunity, knowledge spillovers, and innovative effort', Technovation, 25 (10), 1141-1157.

Rodríguez-Serrano, M. Á., \& Martín-Velicia, F. A. (2015). 'The Role of Absorptive Capability on Born-Global Performance ', Journal of Promotion Management, 21 (4), 447-458.

Schreiber, J. B., Nora A., Stage F. K., Barlow E. A. and King J. (2006) 'Reporting Structural Equation Modeling and Confirmatory Factor Analysis Results: A Review', Journal of Educational Research, 99, 323-337.

Sivo, S. A., Fan X. T., Witta E. L. and Willse J. T. (2006). The Search for 'Optimal' Cutoff Properties: Fit Index Criteria in Structural Equation Modeling '. The Journal of Experimental Education, 74 (3), 267-289.

Ullman, J. B. (2001). Structural equation modeling. In B.G. Tabachnick \& L.S. Fidell (Eds.), Using multivariate statistics (4th Ed.). Needham Heights, MA: Allyn \& Bacon.

Volberda, H. W., Foss, N. J., \& Lyles, M. A. (2010) 'Perspective-absorbing the concept of absorptive capacity: How to realize its potential in the organization field '. Organization science, 21, (4), 931-951.

White, L. (2008). 'The Use of Performance Measures and Their Outcomes ', Journal of American Academy of Business, 13, (1), 133-137.

Zahra, S. A., \& George, G. (2002). 'Absorptive capacity: A review, reconceptualization, and extension ', Academy of management review, 27 (2), 185-203. 


\section{Appendix A:}

Scale items. Results of confirmatory factor analysis.

\begin{tabular}{|c|c|c|c|c|}
\hline & & $\begin{array}{l}\text { Factor } \\
\text { Loadings }\end{array}$ & $\begin{array}{l}\text { Composite } \\
\text { Reliability }\end{array}$ & AVE \\
\hline ACA & Exploitation capacities $(\alpha=\mathbf{0 . 8 8 2})$ & & 0.943 & 0.847 \\
\hline ACA1 & Managers support the development of prototypes & 0.802 & & \\
\hline ACA2 & $\begin{array}{l}\text { The company regularly re-evaluates and adapts } \\
\text { existing technologies in novel ways }\end{array}$ & 0.907 & & \\
\hline ACA3 & $\begin{array}{l}\text { The company has the ability to work more effectively } \\
\text { by adopting new technologies }\end{array}$ & 0.825 & & \\
\hline OP & Organizational performance $(\alpha=0.926)$ & & & \\
\hline OP1 & Return on investment & 0.871 & & \\
\hline OP2 & Profit growth & 0.940 & 0.939 & 0.871 \\
\hline OP3 & Sales growth & 0.853 & & \\
\hline OP4 & Increase market share & 0.810 & & \\
\hline
\end{tabular}

